\title{
Wnt inhibitory factor 1 suppresses cancer stemness and induces cellular senescence
}

\author{
I Ramachandran ${ }^{1,11}$, V Ganapathy ${ }^{1}$, E Gillies ${ }^{2}$, I Fonseca ${ }^{3}$, SM Sureban ${ }^{4,5,6}$, CW Houchen ${ }^{4,5,6}$, A Reis ${ }^{7, \text { * }}$ and L Queimado*,1,4,5,8,9,10
}

Hyperactivation of the Wingless-type (Wnt)/ $\beta$-catenin pathway promotes tumor initiation, tumor growth and metastasis in various tissues. Although there is evidence for the involvement of Wnt/ $\beta$-catenin pathway activation in salivary gland tumors, the precise mechanisms are unknown. Here we report for the first time that downregulation of the Wnt inhibitory factor 1 (WIF1) is a widespread event in salivary gland carcinoma ex-pleomorphic adenoma (CaExPA). We also show that WIF1 downregulation occurs in the CaExPA precursor lesion pleomorphic adenoma (PA) and indicates a higher risk of progression from benign to malignant tumor. Our results demonstrate that diverse mechanisms including WIF1 promoter hypermethylation and loss of heterozygosity contribute to WIF1 downregulation in human salivary gland tumors. In accordance with a crucial role in suppressing salivary gland tumor progression, WIF1 re-expression in salivary gland tumor cells inhibited cell proliferation, induced more differentiated phenotype and promoted cellular senescence, possibly through upregulation of tumor-suppressor genes, such as p53 and p21. Most importantly, WIF1 significantly diminished the number of salivary gland cancer stem cells and the anchorage-independent cell growth. Consistent with this observation, WIF1 caused a reduction in the expression of pluripotency and stemness markers (OCT4 and C-MYC), as well as adult stem cell self-renewal and multi-lineage differentiation markers, such as WNT3A, TCF4, c-KIT and MYB. Furthermore, WIF1 significantly increased the expression of microRNAs pri-let-7a and pri-miR-200c, negative regulators of stemness and cancer progression. In addition, we show that WIF1 functions as a positive regulator of $m i R-200 c$, leading to downregulation of BMI1, ZEB1 and ZEB2, with a consequent increase in downstream targets such as E-cadherin. Our study emphasizes the prognostic and therapeutic potential of WIF1 in human salivary gland CaExPA. Moreover, our findings demonstrate a novel mechanism by which WIF1 regulates cancer stemness and senescence, which might have major implications in the field of cancer biology.

Cell Death and Disease (2014) 5, e1246; doi:10.1038/cddis.2014.219; published online 22 May 2014

Subject Category: Cancer

Salivary gland tumors are clinically diverse and present considerable challenges in both diagnosis and treatment. ${ }^{1}$ The most common salivary gland tumor is pleomorphic adenoma (PA). Although PAs are classified as benign, they are frequently multicentric, tend to recur, undergo malignant transformation and can even metastasize. ${ }^{2}$ Carcinoma ex-PA (CaExPA) is defined as a carcinoma arising from a primary or recurrent benign PA. CaExPA is an aggressive malignancy that frequently metastasizes and has a 5-year survival rate of $\sim 30 \%$. $^{2,3}$ Locoregional recurrence is frequent ( $\sim 40 \%$ ), following surgical resection with or without radiotherapy, and is associated with a median survival of $<1$ year.,3
These tumor features emphasize the urgent need to identify molecular markers of prognosis and to develop novel therapeutic agents for this cancer.

Wingless-type (Wnt)/ $\beta$-catenin signaling pathway regulates key processes such as cell proliferation, differentiation, survival and migration that are essential during embryonic development, adult tissue homeostasis and oncogenesis. ${ }^{4-7}$ $\mathrm{Wnt} / \beta$-catenin signaling contributes to cancer initiation and progression, in part through the maintenance of highly tumorigenic subpopulations of cancer cells called tumorinitiating cells or cancer stem cells (CSCs). ${ }^{8-10}$ Still, different subsets of cells vary in their responsiveness to different

\footnotetext{
${ }^{1}$ Department of Otorhinolaryngology, The University of Oklahoma Health Sciences Center, Oklahoma City, OK, USA; ${ }^{2}$ Department of Pathology, The University of Oklahoma Health Sciences Center, Oklahoma City, OK, USA; ${ }^{3}$ Serviço de Anatomia Patológica, Instituto Português de Oncologia de Francisco Gentil and Instituto de Anatomia Patológica, Faculdade de Medicina de Lisboa, Lisbon, Portugal; ${ }^{4}$ US Department of Veterans Affairs Medical Center, Oklahoma City, OK, USA; ${ }^{5} \mathrm{Peggy}$ and Charles Stephenson Oklahoma Cancer Center, The University of Oklahoma Health Sciences Center, Oklahoma City, OK, USA; ${ }^{6}$ Department of Medicine, The University of Oklahoma Health Sciences Center, Oklahoma City, OK, USA; ${ }^{7}$ Department of Dermatology, The University of Oklahoma Health Sciences Center, Oklahoma City, OK, USA; ${ }^{8}$ Department of Cell Biology, The University of Oklahoma Health Sciences Center, Oklahoma City, OK, USA; ${ }^{9}$ Department of Pediatrics, The University of Oklahoma Health Sciences Center, Oklahoma City, OK, USA and ${ }^{10}$ The Oklahoma Tobacco Research Center, Oklahoma City, OK, USA

*Corresponding author: L Queimado, Department of Otorhinolaryngology, The University of Oklahoma Health Sciences Center, 975 N.E. 10 th Street, BRC 1272 , Oklahoma City, OK 73104, USA. Tel: +1 405271 4232; Fax: +1 405271 9364; Email: lurdes-queimado@ ouhsc.edu

${ }^{11}$ Current address: Department of Endocrinology, Dr. ALM Post Graduate Institute of Basic Medical Sciences, University of Madras, Taramani Campus, Chennai, Tamil Nadu, India

"Deceased: 24 December 2008

Keywords: Wnt inhibitory factor 1 (WIF1); salivary gland tumor; senescence; cancer stem cells; pluripotency; miR-200c

Abbreviations: Wnt, wingless-type; WIF1, Wnt inhibitory factor 1; CaExPA, carcinoma ex-pleomorphic adenoma; PA, pleomorphic adenoma; miRNA, microRNA; CSCs, cancer stem cells; DAC, 5-aza-2'-deoxycytidine; ALDH, aldehyde dehydrogenase; SA- $\beta$-gal, senescence-associated beta-galactosidase

Received 30.10.13; revised 07.4.14; accepted 08.4.14; Edited by A Stephanou
} 
means of $\mathrm{Wnt} / \beta$-catenin pathway activation. ${ }^{11-14}$ In addition, differences in the availability of niche-specific Wnt agonists and antagonists might distinctly modulate CSC self-renewal and differentiation in different cancer types. ${ }^{7,15}$

Hyperactivation of Wnt/ $\beta$-catenin signaling, as measured by cytoplasmic and/or nuclear accumulation of $\beta$-catenin, is relatively rare $(\sim 10 \%)$ in salivary gland $P A$ but frequent ( $\sim 90 \%$ ) in CaExPA, and has been suggested to have a role in the malignant transformation of PA into CaExPA. ${ }^{3,16,17}$ Unfortunately, the mechanisms that lead to $\mathrm{Wnt} / \beta$-catenin activation in PA and CaExPA remain unknown. Earlier, we identified the Wnt inhibitory factor 1 (WIF1), a Wnt pathway antagonist, as a novel gene-fusion partner to HMGA2 gene and a hot spot for recurrent genomic rearrangements in PA. ${ }^{18}$ WIF1 binds directly to extracellular Wnt ligands, such as WNT1, and blocks their interaction with the receptors, leading to $\beta$-catenin proteasomal degradation and Wnt inactivation. ${ }^{19}$ These data suggest that WIF1 might have a role in salivary gland oncogenesis. However, there are no studies on the protein expression level or role of WIF1 in human salivary gland tumors. Moreover, no predictive biomarkers for progression of PA to CaExPA have been discovered yet.

In this study, we found that WIF1 downregulation is a widespread event in CaExPA and its downregulation in PA might predict higher risk of progression to malignancy. Our study shows for the first time that WIF1 inhibits cancer stemness and induces cellular senescence in salivary gland tumor cells. Most importantly, we delineate novel tumorsuppressive mechanisms of WIF1 that underscore WIF1 as a potential anticancer therapeutic agent.

\section{Results}

Downregulation of WIF1 expression in human salivary gland tumors correlates with progression to malignancy. To determine the status of WIF1 in salivary gland tumors, we quantified the expression of WIF1 by immunohistochemistry in two distinct cohorts of matched normal and tumor salivary gland samples obtained from patients diagnosed with PA who progressed (14 cases) or did not progress (71 cases) to CaExPA. In normal salivary gland, WIF1 was detected as an abundant cytoplasmic brown granular staining that was quantified as strong (Figure 1). This staining pattern is consistent with WIF1 normal expression. ${ }^{20}$ In PA samples removed from patients with only a benign tumor (Figure 1a), WIF1 immunostaining was quantified as strong (56 cases) or moderate (13 cases) in $97 \%$ of the cases, and as low (1 case) or undetectable (1 case) in $3 \%$ of the cases (Figure 1d). Overall, no significant difference in WIF1 expression was observed between normal salivary gland and matched PA samples removed from patients with only a benign tumor (Figure 1c). In PA samples obtained from patients that progressed to CaExPA (Figure 1b), 28\% presented with strong (1 case) or moderate (3 cases) WIF1 expression, whereas $72 \%$ presented with low (9 cases) or undetectable (1 case) WIF1 expression (Figure 1d). Furthermore, all 14 PA samples obtained from patients that progressed to CaExPA expressed lower levels of WIF1 (Figures $1 \mathrm{~b}$ and d) than their matched normal epithelium $(P<0.001)$. These data demonstrate that WIF1 downregulation is a frequent event in PA cases that progressed to malignancy. This also suggests that WIF1 downregulation is an early event in salivary gland oncogenesis and might predict a higher risk of progression from PA to CaExPA. In CaExPA samples, WIF1 expression was quantified as low (2 cases) or undetectable (12 cases) in $100 \%$ of the cases (Figure 1d). Moreover, a significant decrease in WIF1 expression $(P<0.000001)$ was observed in CaExPA samples by comparison with adjacent PA (Figure 1c). The pronounced decrease in WIF1 expression from PA to CaExPA suggests that WIF1 could be a critical factor to inhibit PA progression to malignancy.

To determine whether WIF1 downregulation contributes to Wnt/ $\beta$-catenin signaling hyperactivation, we evaluated the levels of $\beta$-catenin by immunohistochemistry in 14 matched samples from each cohort. In normal salivary gland, $\beta$-catenin expression was high in the cell membrane, undetectable in the nucleus and low or undetectable in the cytoplasm. $\beta$-catenin membranar expression was slightly reduced in $57 \%$ of all PA samples, undetectable in three PA cases that progressed to CaExPA and undetectable in $64 \%$ of all CaExPAs (data not shown). Most importantly, increase in cytoplasmic and/or nuclear $\beta$-catenin was only observed in samples that progressed to malignancy (Figure 1e). These data suggest that WIF1 downregulation contributes to $\mathrm{Wnt} / \beta$-catenin signaling hyperactivation.

WIF1 is silenced by promoter hypermethylation and genomic deletions. Promoter methylation is the most frequently reported mechanism leading to WIF1 downregulation in human cancers. ${ }^{21-24}$ To assess WIF1 promoter methylation, we performed methylation-specific PCR (MSP). An unmethylated band was observed in normal salivary gland (Figure 2a). In contrast, both methylated and unmethylated bands were amplified in all the malignant tumors and cell lines tested (Figure 2a and Supplementary Figure 1a). To confirm WIF1 promoter hypermethylation, we performed bisulfitesequencing analysis in salivary gland primary tumors and cell lines. No hypermethylation was observed in normal salivary gland (Figure $2 \mathrm{~b}$ ) or in PA that did not progress to CaExPA (data not shown). However, promoter hypermethylation (Figure 2b) was present in all malignant tumors tested (cases 6, 9, 13 and 14 presented in Figure 2a). In addition, WIF1 was methylated at baseline in cell lines (Supplementary Figure 1b). Together, these data show that WIF1 promoter hypermethylation occurs frequently in CaExPA. Treatment of salivary gland tumor cell lines with 5-aza-2'-deoxycytidine (DAC), a demethylating agent, removed a significant part of the methylation from $\mathrm{CpG}$ sites and caused a significant increase $(P<0.0001)$ in WIF1 mRNA expression (Supplementary Figure 1). As only a few CpG sites were hypermethylated in the WIF1 promoter, our data suggest that methylation of these CpG sites suffices for DNA-methylationmediated gene silencing. Nevertheless, we cannot rule out the possibility of other WIF1 promoter regions being methylated. These results demonstrate that promoter hypermethylation contributes to the downregulation of WIF1 expression in salivary gland tumors.

WIF1 maps to 12q13-15, a chromosomal region in which genomic loss has been suggested to identify a subset 


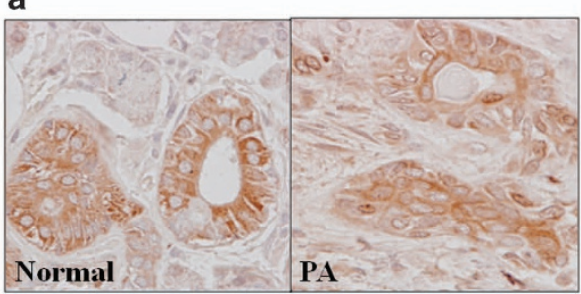

b

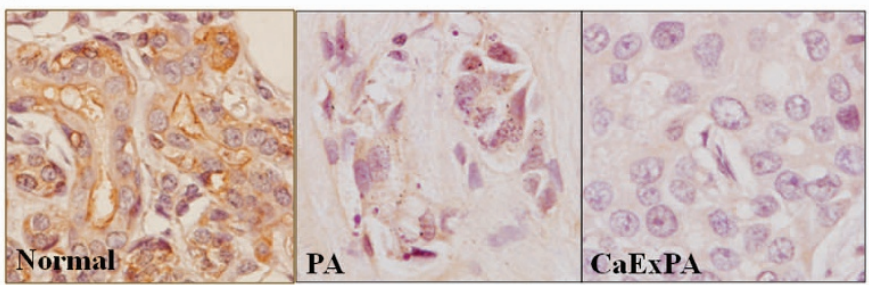

C

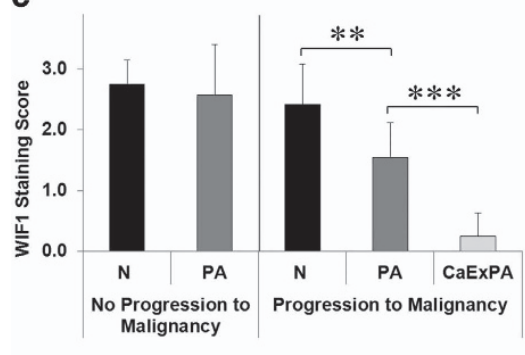

d

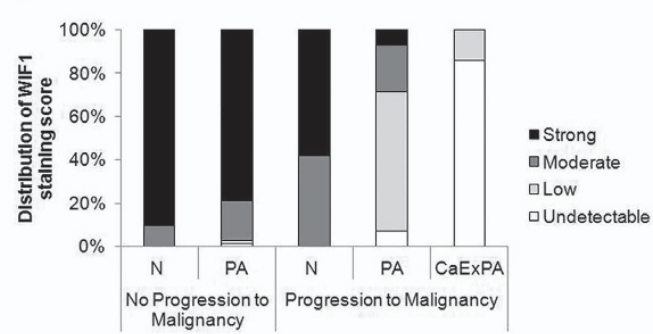

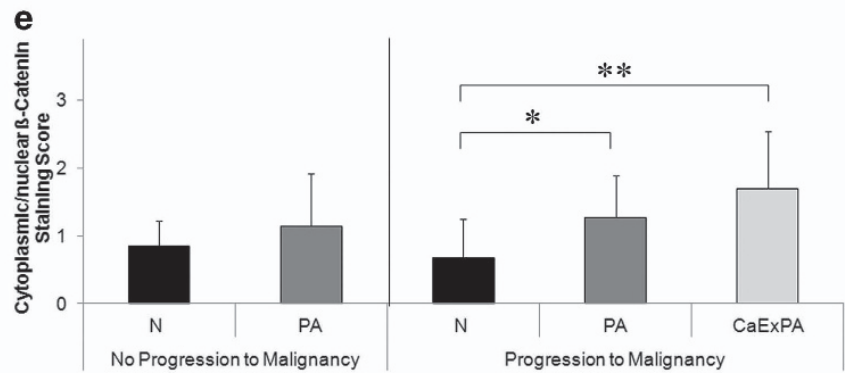

Figure 1 Downregulation of WIF1 occurs early in salivary gland oncogenesis and associates with progression to malignancy. (a) Representative sections of WIF1 expression in matched normal salivary gland and PA in a case that did not progress to malignancy. (b) Representative sections showing WIF1 immunostaining in a PA case that progressed to malignancy (CaExPA). Shown are matched normal salivary gland, PA and CaExPA. Original magnification, 600X. (c) Quantification of WIF1 immunostaining in 71 PA cases that did not progress to malignancy (matched normal and PA) and 14 cases that progressed to malignancy (matched normal, PA and $\mathrm{CaExPA}$ ). (d) Distribution of the WIF1 immunostaining scores (in percentage) in different tissues and cohorts. (e) Quantification of $\beta$-catenin immunostaining in 14 PA cases that did not progress to malignancy (matched normal and PA) and 14 cases that progressed to malignancy (matched normal, PA and CaExPA). Immunostaining scored as 0 (undetectable), 1 (low), 2 (moderate) or 3 (strong). Data are the mean \pm S.D. ${ }^{*} P<0.01,{ }^{\star \star} P<0.001,{ }^{* \star *} P<0.000001$

of PA with higher potential for malignant transformation. ${ }^{25}$ Therefore, we determined whether loss of heterozygosity (LOH) involving WIF1 occurs in CaExPA. Three of the four CaExPA cases studied (for which constitutional DNA was available) were informative for at least one microsatellite marker within 12q13-15. Two of those had LOH involving the WIF1 locus (Figure 2c). Importantly, both cases also showed WIF1 promoter hypermethylation (Figure 2b). These data suggest that both genetic and epigenetic mechanisms contribute to WIF1 inactivation in salivary gland CaExPA.

WIF1 inhibits tumor cell proliferation and induces cell cycle arrest. We have previously demonstrated that WIF1 mRNA expression is undetectable in PA or
CaExPA cell lines. ${ }^{18,26}$ Accordingly, WIF1 expression is low or undetectable in most PAs that progressed to CaExPA and undetectable in the majority of CaExPA patient samples (Figure 1). To determine the potential growth inhibitory effects of WIF1, we first attempted to stably transfect salivary gland tumor cells with a vector that expresses full-length WIF1 protein (hereafter referred as WIF1). Importantly, no viable clones were obtained from stably transfected salivary gland tumor cells. In contrast, numerous WIF1 stable clones were obtained for the control cell line (HEK-293). These results prompted us to focus on transient transfection studies. PA and CaExPA cells were transiently transfected with WIF1 and assessed for WIF1 expression and cell proliferation. Re-expression of WIF1 resulted in a significant 
growth inhibition $(P<0.0001)$ in both PA (Supplementary Figure 2a) and CaExPA (Figure $3 a$ ) cells at all time points. Despite transient transfection, our data show that WIF1 persists at high concentration in the conditioned media for at least 14 days post transfection (Supplementary Figure 2b).

We then investigated whether apoptosis and cell cycle arrest contributed to the growth-suppressive effects of WIF1. Re-expression of WIF1 in CaExPA cells induced a small but significant increase in apoptosis (Figure $3 b$ ), as well as in the number of cells accumulating in $\mathrm{G}_{1}$ phase of the cell cycle (Figure $3 c$ ). These data suggest that other tumor-suppressive mechanisms have a major role in the reduction of tumor cell proliferation caused by WIF1.

WIF1 induces cellular senescence. WIF1 re-expression led to the appearance of a high number of large and flat cells with frequent dendritic terminations and enhanced cytoplasmic granularity (Figures $4 a$ and b). Multinucleated cells were also common. These features are characteristics of more differentiated and senescent cells. ${ }^{27}$ To quantify this effect, cells were stained for senescence-associated beta-galactosidase (SA- $\beta$-gal). WIF1 increased the number
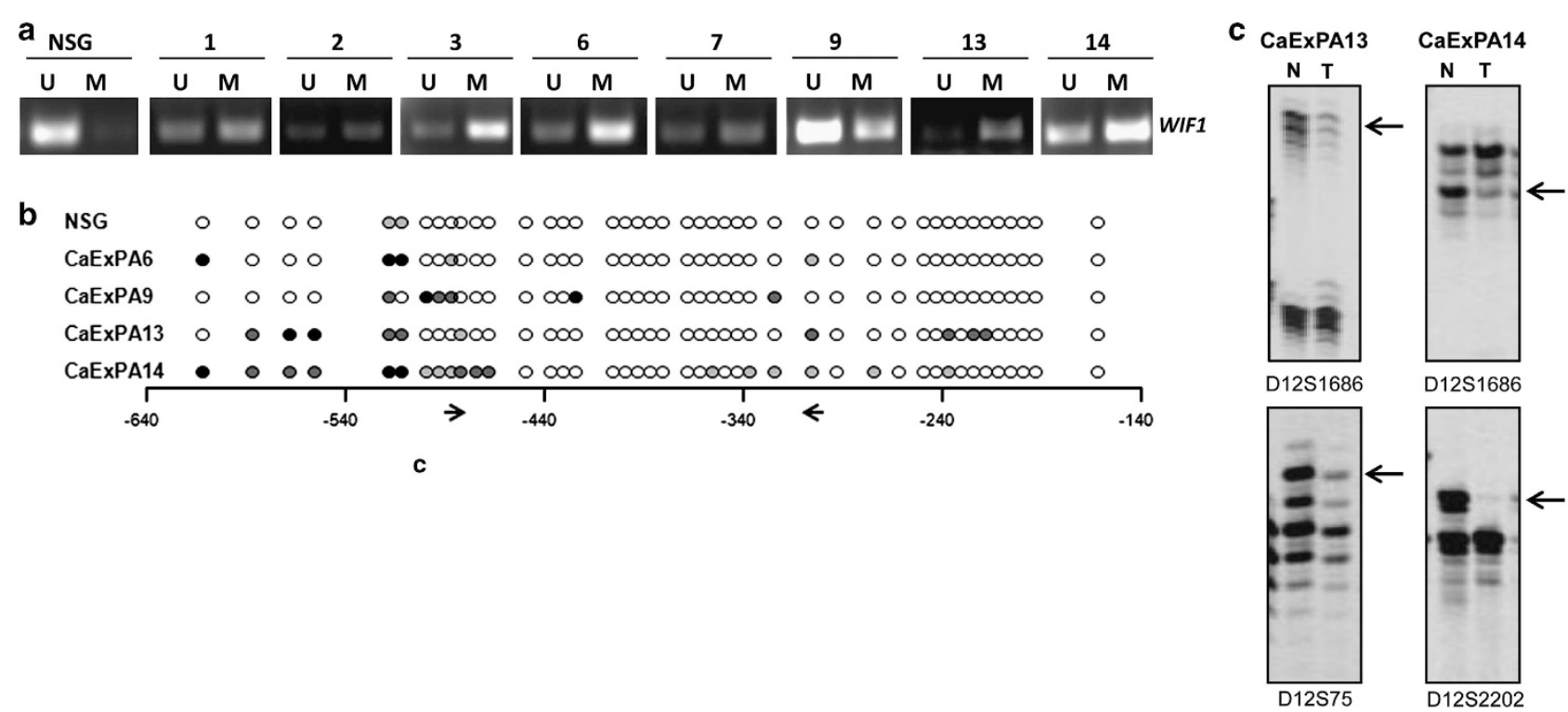

Figure 2 Promoter hypermethylation and genomic deletion contribute to WIF1 downregulation in human salivary gland tumors. (a) Methylation-specific PCR analysis shows that WIF1 promoter is unmethylated in normal salivary gland but hypermethylated in eight primary CaExPA tissues. U, unmethylation-specific PCR product; M, methylation-specific PCR product. Case numbers are mentioned on the top. (b) Schematic representation of frequency of methylation observed by bisulfite-sequencing analysis at CpG sites in the WIF1 promoter (region -639 to -140) of salivary gland normal (NSG) and CaExPA tissues. Shown are a representative sample of NSG used as control and four primary CaExPA for which enough DNA was available. MSP primers are shown in arrows. The methylation frequency of each $\mathrm{CpG}$ site (circle) is represented by the color of the circle: $51-100 \%$ (black), $25-50 \%$ (dark gray), 1-24\% (light gray) or $0 \%$ (white). (c) Four primary CaExPA for which matching constitutional DNA was available were analyzed for 10 microsatellite markers within the long arm of chromosome 12 (12q). Six of these markers map to 12q13-15. Shown are representative examples of LOH within 12q13-15, a region that includes WIF1 loci. Allelic losses are indicated by arrows. T, tumor DNA; N, constitutional DNA
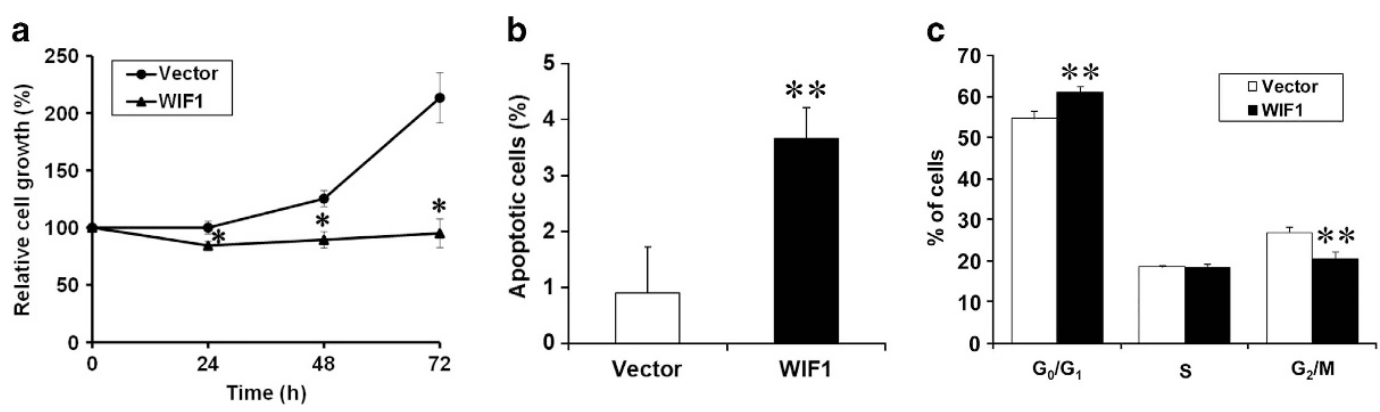

Figure 3 WIF1 inhibits tumor cell proliferation and induces cell cycle arrest and apoptosis in salivary gland tumor cells in vitro. (a) CaExPa79 cells were simultaneously transfected with either vector or $\mathrm{pCl}$ blast-WIF1 using LipoD293 transfection reagent, and cell proliferation was assessed at different time points (24, 48 and $72 \mathrm{~h})$ by hexosaminidase assay. (b) WIF1 induces apoptosis and (c) $\mathrm{G}_{1}$ cell cycle arrest. CaExPA79 cells were transfected with vector or pCl blast-WIF1 for $48 \mathrm{~h}$, the floating and attached cells were collected, centrifuged and processed for flow cytometry. Fifty thousand events were captured for each sample and results were analyzed with ModFit $L T$ software (Verity Software House, Topsham, ME, USA). Data are the mean \pm S.D., $n=3 .{ }^{*} P<0.001,{ }^{* \star} P<0.01$ 
of SA- $\beta$-gal-positive cells $(P<0.0001)$ compared with vector (Figures $4 \mathrm{a}$ and b). As WIF1 re-expression significantly reduces the total number of cells per field (30-50\%), the absolute increase in senescent cells is remarkably higher than the relative number shown in Figures $4 a$ and $b$. To gain insights into the molecular mechanisms leading to cellular senescence, we examined the expression levels of critical senescence factors. WIF1 induced a remarkable increase in both mRNA and protein expression of p53 and its target p21 (Figures 4c and d). p21 is one of the key mediators of
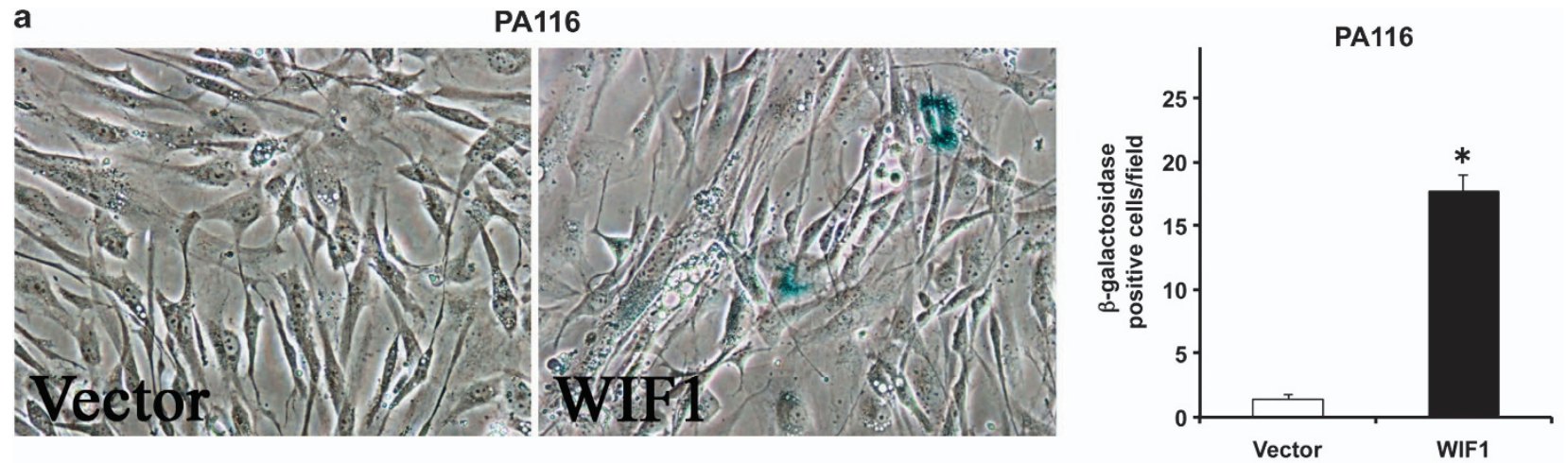

b

CaExPA79
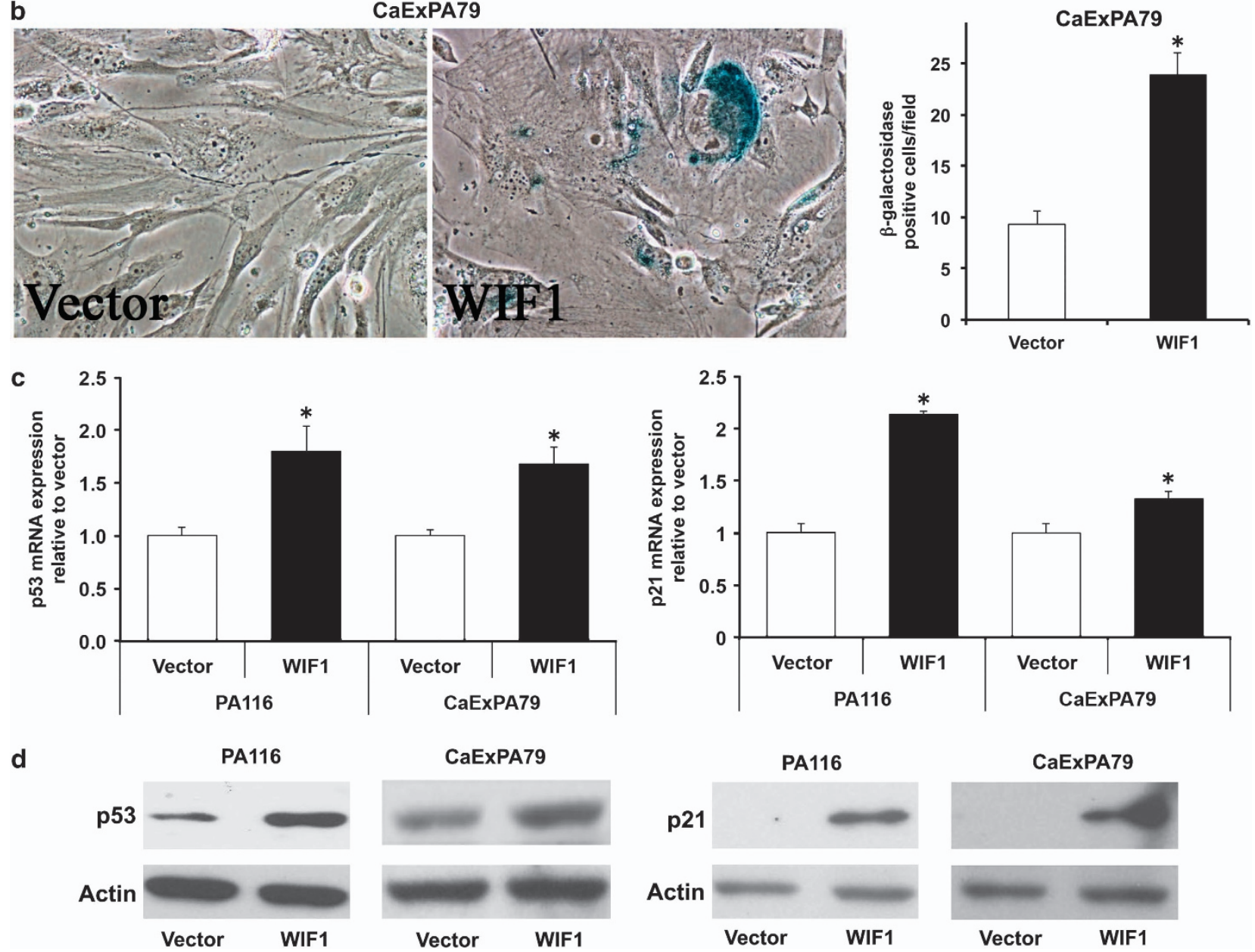

CaExPA79

CaExPA79
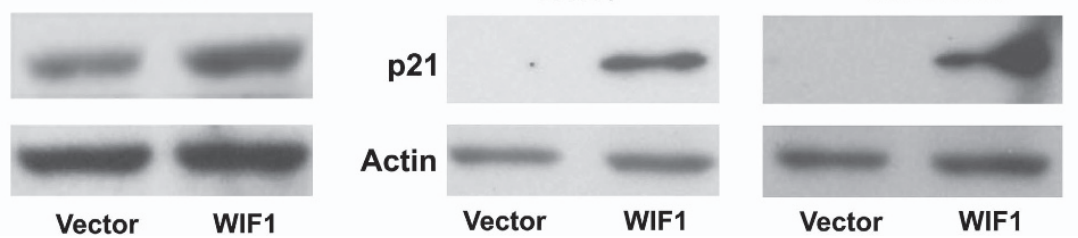

Figure 4 WIF1 induces cellular senescence through upregulation of p53 and p21 expression in salivary gland tumor cells. (a) PA116 and (b) CaExPA79 cells were transfected with vector or WIF1 for $48 \mathrm{~h}$ and stained (left and middle panels) for senescence-associated $\beta$-galactosidase (SA- $\beta$-gal), defined as beta-galactosidase activity detectable at pH 6.0 in senescent cells (blue color). Original magnification, $\times 400$. The number of blue color positive cells per $\times 40$ field was assessed in PA116 (a, right panel) and CaExPA79 (b, right panel) cells. Data are the mean \pm S.D., $n=3 .{ }^{*} P<0.0001$. (c) Total RNA isolated from WIF1-transfected PA116 and CaExPA79 cells was subjected to real-time RT-PCR and relative mRNA expression of p53 (left panel) and p21 (right panel) was assessed. The transcripts were normalized with $\beta$-actin. Data are the mean \pm S.D., $n=3$. ${ }^{*} P<0.0001$. (d) Total protein extracts from WIF1-transfected PA116 and CaExPA79 cells were analyzed by western blotting, detecting p53 (left) and p21 (right) protein expression. The same blots were probed for actin as a loading standard 
p53-induced senescence. Increase in the expression of p21 mediated through increased trans-activation of p53 via WIF1, most likely results in WIF1-induced senescence.

WIF1 reduces the number of salivary gland tumor stem cells. WIF1 acts by sequestering secreted Wnt proteins, such as WNT3A, that can act as a stem cell self-renewal factor. ${ }^{28}$ To determine whether WIF1 regulates salivary gland tumor stem cells, we transfected PA116 and CaExPA79 cells with WIF1 and sorted the cells by FACS based on aldehyde dehydrogenase (ALDH) activity. Enhanced ALDH activity is a hallmark of $\mathrm{CSCs}^{29}$ and an accepted salivary gland CSC marker. ${ }^{30-32}$ WIF1 caused reduction $(P<0.001)$ in the number of ALDH-positive cells by $55 \%$ and $73 \%$ in PA116 and CaExPA79, respectively (Figure 5a). These data show that WIF1 reduces the number of salivary gland tumor stem cells.

WIF1 reduces anchorage-independent growth of salivary gland tumor cells. To determine the effect of WIF1 on anchorage-independent growth, we performed sphere-forming assays. WIF1 significantly $(P<0.001)$ reduced the number of spheroids in both PA116 and CaExPA79 cell lines by day 5 (Figure $5 b$ ). Prolonging the culture to 14 days increased the number of spheroids in vector-transfected CaExPA79 cells $(P<0.001)$, but not in PA116 cells (Figure $5 b$ ). This observation pinpoints a significant difference between the cancerous (CaExPA79) and benign (PA116) cells and might reflect a population of CaExPA79 quiescent cells that re-enter clonal growth at later time points. Importantly, we observed no increase in the total number of spheroids from day 5 to day 14 in WIF1-transfected cells. These data suggest that the effects of WIF1 are long lasting. By day 5, the size of the spheroids formed in cultures expressing WIF1 was also remarkably smaller than in vector-transfected cultures (Figure $5 \mathrm{c}$ ). Prolonging the culture to 14 days increased the size of the spheroids only in vector-transfected cultures (Figure $5 \mathrm{c}$ ). Furthermore, while the cells present on the spheroid rim of vector-transfected cultures looked healthy up to 14 days, the cells on the spheroid rim of WIF1-transfected cultures looked unhealthy (non-spherical, undefined borders and broken) as early as day 5 (Figure $5 \mathrm{c}$ and data not shown). Taken together, our data show that WIF1 inhibits the anchorageindependent growth of salivary gland tumor cells, and suggest that WIF1 causes an irreversible proliferation arrest and/or differentiation of cells that exhibit stem cell traits.

WIF1 reduces the expression of master regulators of stem cell self-renewal and pluripotency. Transcription factor networks have emerged as the master regulatory mechanisms of stem cell pluripotency and differentiation. ${ }^{33}$ OCT4 and C-MYC are highly expressed in pluripotent cells and have a central role in the regulation of pluripotency and self-renewal. ${ }^{34}$ Consistent with WIF1 suppressing salivary gland stem cell self-renewal and inducing differentiation, WIF1 induced a significant reduction in OCT4 and $c-M Y C$ expression (Figure $5 \mathrm{~d}$ ) in CaExPA79 cells. In addition, WIF1 caused a significant downregulation of WNT3A and TCF4 (Figure 5d), key WNT pathway components with recognized roles in stem cell self-renewal and maintenance. ${ }^{35,36}$
WIF1 also downregulated $c-K I T$ and MYB (Figure 5d). Both genes are frequently overexpressed in salivary gland cancer, ${ }^{37-39}$ and promote stem cell self-renewal. ${ }^{40-42} \mathrm{c}$-KIT is the only functionally tested marker for normal salivary gland stem cells in mouse. ${ }^{43}$ Our data suggest that c-KIT could also be an important marker for human salivary gland CSCs. Collectively, our data show that WIF1 reduces the expression of several genes with critical roles in salivary gland CSC self-renewal and pluripotency.

WIF1 regulates the expression of microRNAs with a critical role in salivary gland stemness and oncogenesis. MicroRNAs (miRNA) are small noncoding RNAs that are key regulators of stem cell self-renewal and differentiation. ${ }^{44}$ As miRNAs modulate target genes tissue specifically, we determined whether WIF1 regulates the expression of miRNAs reported to have critical roles in salivary gland development and/or oncogenesis. ${ }^{45,46}$ Particularly relevant to our study are miR-144 and let-7a, which target PA oncogenes (PLAG1 and HMGA2), and miR-21 and miR-200c, the only two miRNAs documented to regulate salivary gland morphogenesis. ${ }^{46}$ WIF1 significantly increased the expression of pri-miR-144 (Figure 6a) and pri-let-7a (Figure $6 \mathrm{~b}$ ) in PA116 and CaExPA79. Downregulation of these miRNAs has been reported in PA and associated with dedifferentiation, cell proliferation and cancer progression. ${ }^{45,47,48}$ Consistent with miR-21 being upregulated in PA samples, ${ }^{45}$ WIF1 decreased pri-miR-21 expression in PA116 cells (Figure 6c). However, WIF1 increased pri-miR-21 expression in CaExPA79 cells. This might reflect the fact that CaExPA contains mainly epithelial cells and/or a different role for miR-21 in CaExPA. A significant increase in pri-miR-200c by WIF1 was observed in both PA116 and CaExPA79 cells (Figure 6d). miR-200c suppresses CSC self-renewal and proliferation, and induces apoptosis, senescence and differentiation. ${ }^{49-51}$ Collectively, our data suggest that WIF1 exerts its tumor-suppressive effects in part by regulating miRNAs that have critical roles in salivary gland CSC self-renewal, differentiation and cancer progression.

WIF1 increases the expression and activity of the tumorsuppressor miRNA miR-200c. Among the miRNAs we studied, pri-miR-200c showed the highest induction following WIF1 re-expression in both benign and malignant cell lines (Figure 6d). miR-200c and its target genes have very important roles in cancer stemness, tumorigenicity and epithelial-mesenchymal transition. ${ }^{52,53}$ By using a luciferase reporter gene assay, we documented a significant reduction in miR-200c-dependent luciferase activity in cells transfected with WIF1 (Figure 6e). This confirms that WIF1 increase in miR-200c expression results in a correspondent increase in miR-200c activity. Most importantly, WIF1 caused a significant reduction in the expression of miR-200c-targeted genes such as ZEB1, ZEB2 and BMI1 (Figure 6f), and increase in E-cadherin (Figure 6f), a primary ZEB1 target. Thus, our studies identify a novel tumor-suppressor mechanism by which WIF1 positively regulates miR-200c expression and activity, and thereby could have reduced cancer stemness, and, induced senescence and a more epithelial phenotype. 

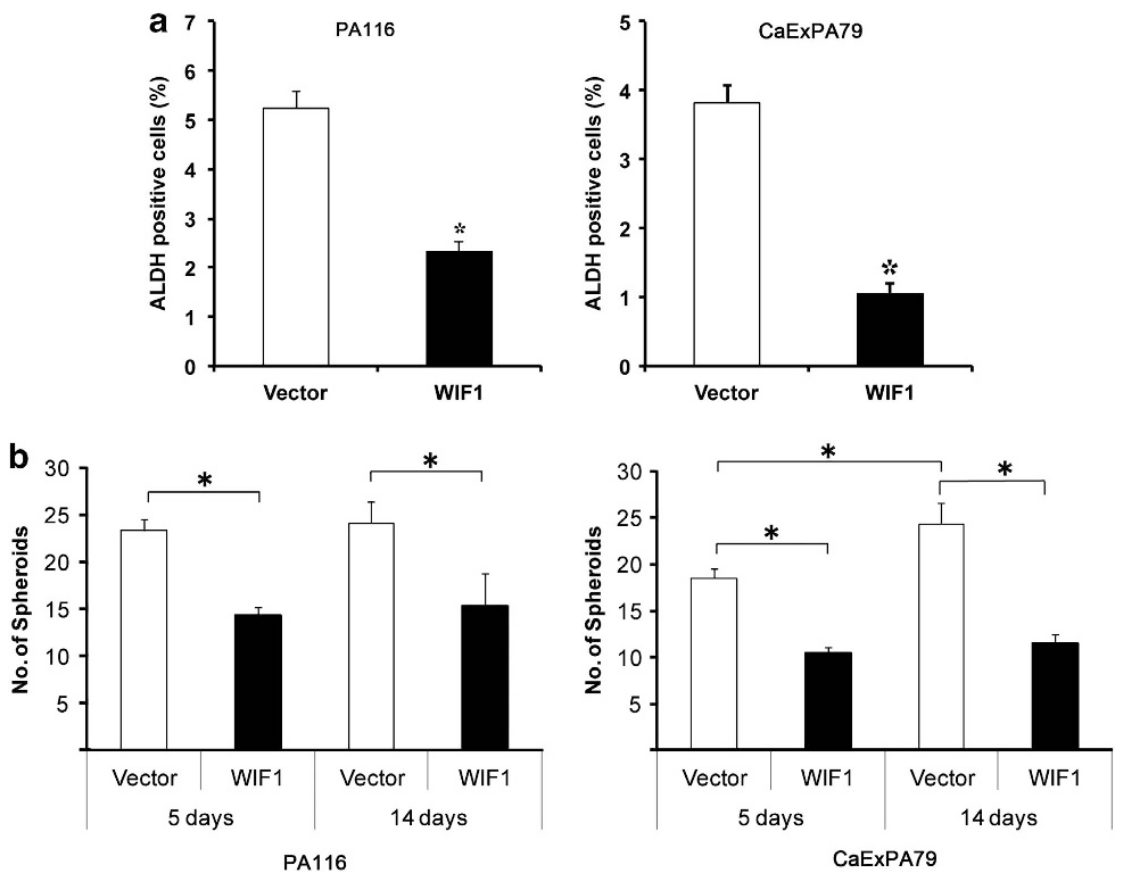

c

PA116

CaExPA79
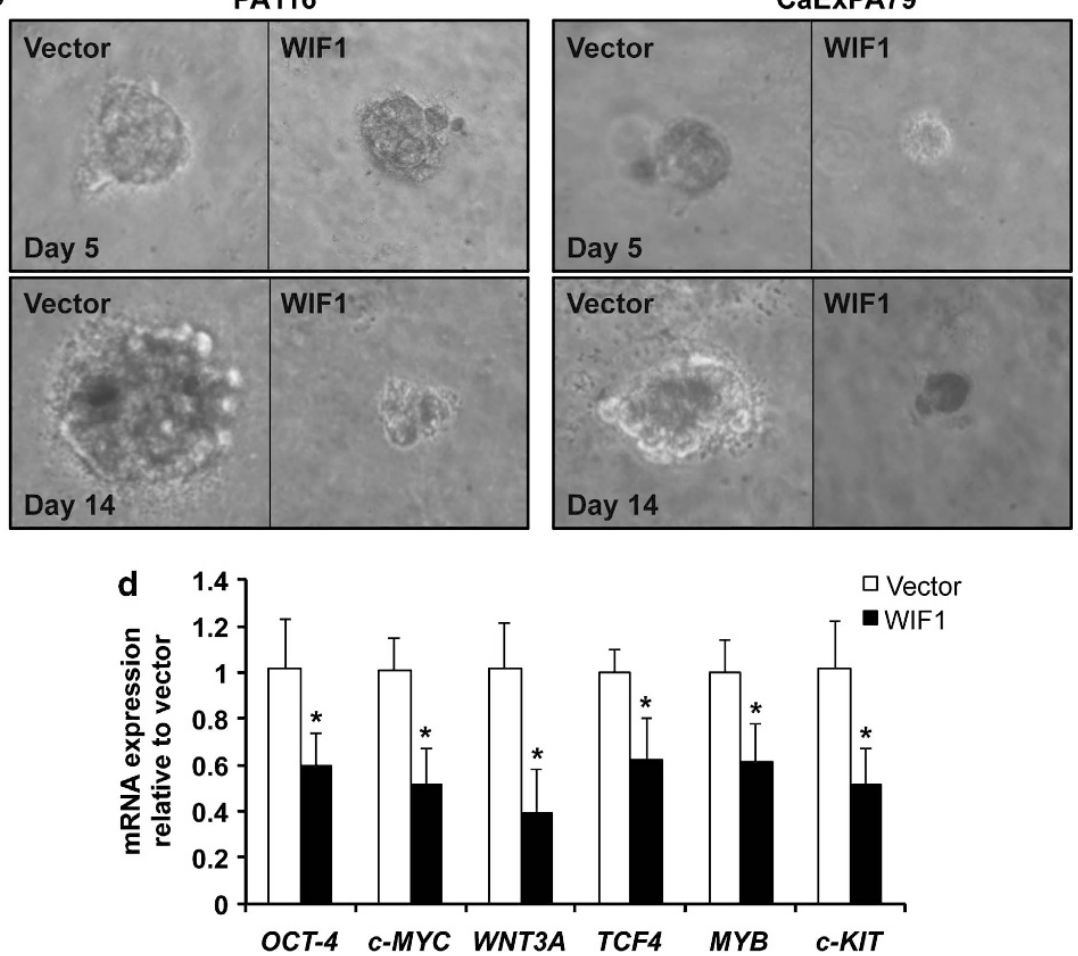

Figure 5 WIF1 reduces salivary gland tumor stemness and the expression of several genes with critical roles in stem cell self-renewal and pluripotency. (a) PA116 and CaExPA79 cells were transfected with vector or WIF1 and $48 \mathrm{~h}$ later sorted by FACS-based on aldehyde dehydrogenase (ALDH) activity. Data are the mean \pm S.D., $n=3$. ${ }^{*} P<0.001$. (b) PA116 (left panel) and CaExPA79 (right panel) cells transfected with vector or WIF1 were assessed for their ability to form spheroids in soft agar. The number of spheroids per well was counted on day 5 and 14. Data are the mean \pm S.D., $n=3 .{ }^{*} P<0.001$. (c) Representative photo images of PA116 (left panel) and CaExPA79 (right panel) cells at day 5 (top panel) and 14 (bottom panel). Original magnification, 400X. (d) Total RNA isolated from CaExPA79 cells transfected with WIF1 was subjected to realtime RT-PCR and relative mRNA expression of OCT4, C-MYC, WNT3A, TCF4, MYB and $c-K I T$ was assessed. The transcripts were normalized with $\beta$-actin. Data are the mean \pm S.D., $n=3 .{ }^{*} P<0.0001$ 

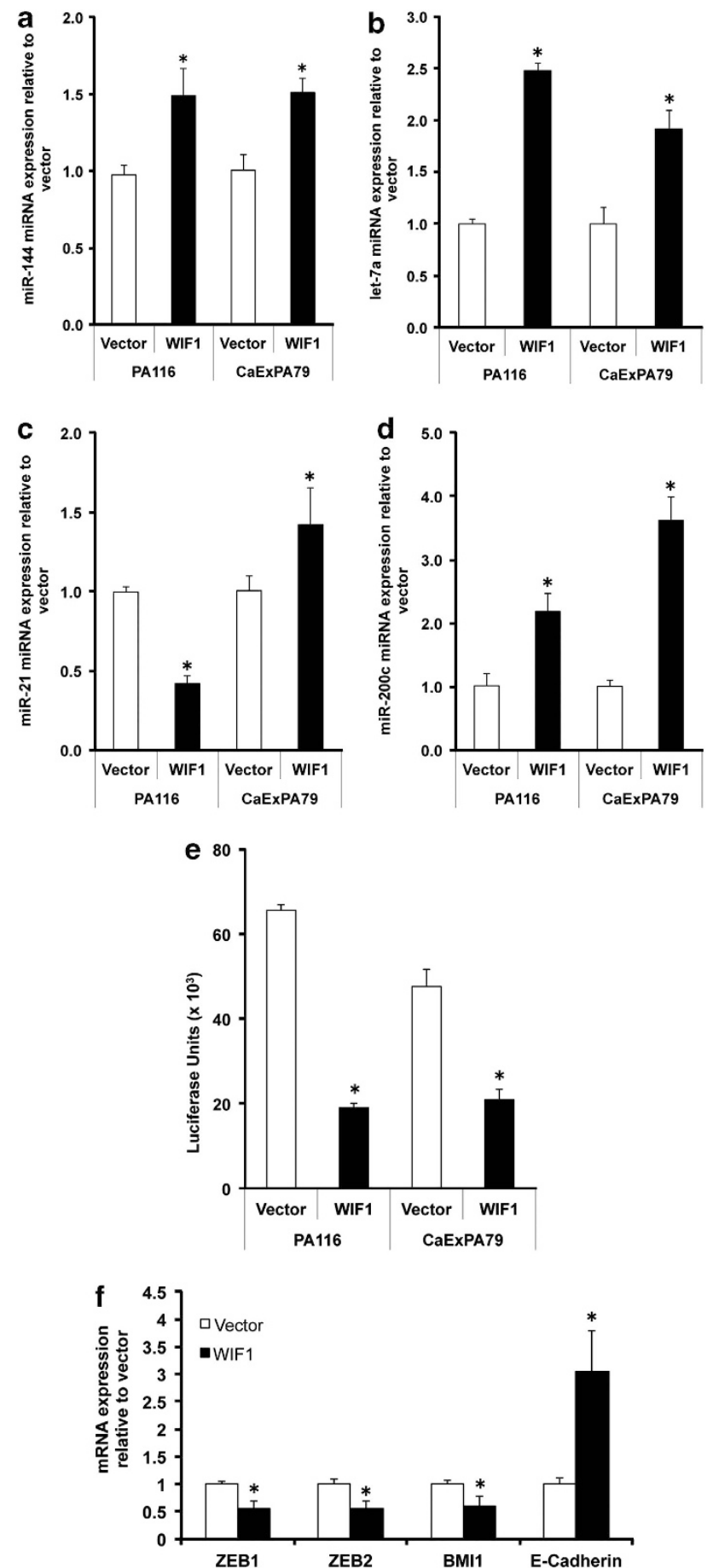

Figure 6 WIF1 modulates the expression of miRNAs that have critical role in salivary gland stemness and oncogenesis. PA116 and CaExPA79 cells transfected with WIF1 for $48 \mathrm{~h}$ were used for total RNA isolation and subjected to real-time RT-PCR for pri-miR-144 (a), pri-let-7a (b), pri-miR-21 (c), pri-miR-200c and (d) miRNA expression analyses. The transcripts were normalized with U6 pri-miRNA. (e) PA116 and CaExPA79 cells were simultaneously transfected with a plasmid containing firefly luciferase gene with a complementary miR-200c binding site in the 3' UTR, along with WIF1 plasmid and pRL-TK, to control for transfection efficiency. The luciferase activity was then determined. (f) CaExPA79 cells transfected with WIF1 for $48 \mathrm{~h}$ were used for total RNA isolation and subjected to real-time RT-PCR for mRNA expression of miR-200c downstream targets ZEB1, ZEB2, BMl1 and E-cadherin. The transcripts were normalized with $\beta$-actin. Data are the mean \pm S.D., $n=3 .{ }^{*} P<0.001$

\section{Discussion}

WNT signaling can promote tumor initiation, progression and drug resistance in a cancer-stage-specific and a cancertype-specific manner. ${ }^{7}$ WIF1 is a potent extracellular Wnt antagonist, a recurrent target for genomic rearrangement in salivary gland $\mathrm{PA}$, and an attractive target for cancer therapy. ${ }^{7,18}$ Here we demonstrate that WIF1 downregulation is a widespread event in human salivary gland CaExPA. Most importantly, we show that WIF1 downregulation occurs at a high frequency in PAs that progressed to CaExPA, but is rare in PAs that did not progress to malignancy. Our studies show that in addition to WIF1 genomic rearrangement, ${ }^{18} \mathrm{LOH}$ and promoter hypermethylation contribute to WIF1 downregulation in CaExPA. Therefore, we suggest that WIF1 expression could be considered in routine histopathology analysis of PA samples, as it might indicate a higher risk of progression from PA to CaExPA.

WIF1 inhibited the proliferation of salivary gland tumor cells. Our results are consistent with previous reports that show that WIF1 induces cell growth inhibition in diverse cancer cell lines. ${ }^{7}$ However, the precise mechanisms leading to cell growth inhibition vary between cell lines. WIF1 induces extensive apoptosis in some cancer cell lines, ${ }^{21,22,54}$ but no significant apoptosis in others. ${ }^{55}$ In our study, WIF1 induced apoptosis in a relatively small population of tumor cells. However, WIF1 induced a striking increase in senescent cells, suggesting that WIF1 reduces salivary gland tumor cell proliferation mainly by inducing senescence. Cellular senescence is an important barrier to proliferation and a crucial anticancer defense. ${ }^{56}$ This anti-proliferative effect may be at least in part caused by the inhibition of $\mathrm{Wnt} / \beta$-catenin signaling by WIF1, as supported by significant changes in the $\beta$-catenin target gene expression ( $c-M Y C, O C T 4$, WNT3A and E-cadherin). WIF1 has been shown to induce senescence in glioblastoma cells. ${ }^{57}$ In contrast, excessive activation of $\mathrm{Wnt} / \beta$-catenin signaling induces senescence of mesenchymal stem cells. ${ }^{58}$ The anti-proliferative effects of WIF1 could also have resulted from an increase in p53 and miR200c, as well as an increase in their downstream target p21, a major mediator of $G_{1}$ arrest and cellular senescence. WIF1 can also induce either $G_{1}$ arrest ${ }^{23,55}$ or $G_{2} / M$ arrest in cancer cells. ${ }^{21}$ These differences may be due to differences in p53 expression, as p53 can regulate both $G_{1}$ and $G_{2} / M$ checkpoints. ${ }^{59}$ We have demonstrated that WIF1 increased p53 and p21 expression in salivary gland tumor cell lines (this study) and in cervical cancer. ${ }^{21}$ Others have shown that WIF1 promoter hypermethylation correlates with loss of p53 expression. ${ }^{60}$ p53 has been shown to regulate the expression of Wnt genes and suppress the $\mathrm{Wnt} / \beta$-catenin signaling. ${ }^{61,62}$ Our data suggest for the first time the existence of a positive feedback by which WIF1 regulates the expression of $\mathrm{p} 53$. These data highlight the context-dependent role of Wnt signaling and the need to dissect the Wnt signaling functions within cell and tissue-specific contexts.

Wnt signaling has been repeatedly implicated in stem cell fate, however, its role remains controversial. ${ }^{63}$ Furthermore, its role on human salivary gland CSCs is unexplored. We demonstrate that WIF1 caused a striking decrease in salivary 
gland CSC number as assessed by a reduction in cells with enhanced ALDH activity and spheroid formation, an in vitro measure of stem cell self-renewal and pluripotency. Selfrenewal is driven by niche factors, such as WNT3A, without which cells tend to differentiate. ${ }^{28}$ WIF1 binds to WNT3A and antagonistically blocks WNT3A-dependent activation of the Wnt/ $\beta$-catenin pathway. ${ }^{64}$ Here, we show that WIF1 suppresses human salivary gland CSC self-renewal at least in part through inhibition of $\mathrm{Wnt} / \beta$-catenin signaling. Accordingly, we observed downregulation of WNT3A, TCF4, OCT4 and $c-M Y C$, as well as an increase in let-7a, all of which have essential roles in stem cell self-renewal and/or pluripotency. ${ }^{34-36,65}$ WIF1 also decreased the expression of $c-K I T$ and $M Y B$, two key genes involved in salivary gland stem cell self-renewal and oncogenesis. ${ }^{37-40}$ Consistent with our data, Wnt signaling promotes stem cell expansion in mouse salivary gland. ${ }^{66}$ The reduction in salivary gland CSCs by WIF1 could also have been achieved through the differential regulation of miRNAs, such as let-7a and miR-200c, which have been shown to block CSC self-renewal and spheroid formation. ${ }^{47,50}$ Studies have shown that miR-200c reduces epithelial proliferation and induces differentiation during mouse salivary gland morphogenesis. ${ }^{67}$ Importantly, our functional and mRNA expression studies demonstrate that WIF1 is a positive regulator of miR-200c activity. Our study shows for the first time a functional link between WIF1 and miR-200c, and reveals a novel mechanism by which WIF1 could suppress salivary gland tumor progression. Collectively, our findings demonstrate that WIF1 elicits its tumor-suppressive effects by modulating the expression of several genes with critical roles in stem cell self-renewal, pluripotency and cancer progression.

Despite exhaustive attempts, none of the only three CaExPA cell lines published initiated tumor formation in mouse xenograft models as observed by us and others (unpublished data). This current technical limitation prevented us from performing in vivo studies as there are no animal models for this cancer. Nonetheless, our current findings are of major clinical significance, as they strongly support a tumorsuppressive role of WIF1 in salivary gland cancer.

In conclusion, we demonstrate for the first time that WIF1 downregulation is a frequent event in salivary gland CaExPA and identifies a subgroup of PA patients at high risk of progression to CaExPA. Most importantly, our study uncovered novel molecular mechanistic pathways by which WIF1 regulates cancer stemness and cellular senescence that might have broader implications in basic biology and could lead to the development of effective molecular therapies to cure human cancer.

\begin{abstract}
Materials and Methods
Human studies. After Institutional Review Board approval, paraffinembedded primary tumor tissues of 85 patients with primary salivary gland tumors with a PA component (71 benign cases and 14 malignant cases) treated with surgery at the University of Oklahoma Health Sciences Center, Oklahoma, USA or at the Portuguese Institute of Oncology, Lisbon, Portugal were included in this study. None of the patients had received preoperative chemotherapy or radiotherapy. The classification of the neoplasms was based on the World Health Organization's criteria for salivary gland tumors. ${ }^{68}$
\end{abstract}

Immunohistochemistry. Immunohistochemistry was performed as we previously reported. ${ }^{21}$ In brief, human tissue samples were fixed in $10 \%$ neutral-buffered formalin and paraffin-embedded. Four micrometer sections were cut and deparaffinized in Histoclear. Heat-induced epitope retrieval was performed on sections using a pressurized de-cloaking chamber (Biocare Medical, LLC, Concord, CA, USA) and incubated in citrate buffer (pH 6.0) at $99{ }^{\circ} \mathrm{C}$ for $18 \mathrm{~min}$. The sections were then washed thrice with PBS and endogenous biotin activity was blocked using Avidin/Biotin blocking kit (Vector Laboratories, Burlingame, CA, USA) according to manufacturer's instructions. Further, endogenous peroxidase activity was quenched with $0.3 \%$ hydrogen peroxide in methanol. The sections were blocked with $10 \%$ normal serum for $30 \mathrm{~min}$ to prevent non-specific binding and then incubated overnight with the primary antibody $(1: 100)$ for WIF1 (Santa Cruz Biotechnology, Santa Cruz, CA, USA) and anti-active $\beta$-catenin (anti-ABC; Upstate, Temecula, CA, USA). The biotinylated secondary antibody (Vector Laboratories) was used at a dilution of $1: 400$. The slides were further processed by using a Vectastatin ABC kit (Vector Laboratories). Antibody binding was visualized using 3,3'-diaminobenzidine (Sigma-Aldrich, St. Louis, MO, USA) as chromogen. Nuclei were counterstained with Mayer's hematoxylin. A negative control sample was included in each run by omitting the primary antibody. For statistical analysis, the intensity of WIF1 or $\beta$-catenin immunostaining was scored as 0 (negative), 1 (low), 2 (moderate) and 3 (strong) in human tissues. ${ }^{21}$

Microscopic examination. Tissue sections were examined using Nikon $80 \mathrm{i}$ microscope base. Digital images $(\times 600)$ were taken with PlanAPO objectives and DXM1200C camera (Nikon, Melville, NY, USA). All images were captured using NIS-Elements software (Nikon).

Methylation-specific PCR. Genomic DNA was extracted from normal and CaExPA samples, and salivary gland tumor cell lines as we previously described. ${ }^{69}$ Bisulfite modification of genomic DNA was carried out using the EZ DNA Methylation Kit (Zymo Research, Irvine, CA, USA). Bisulfite-modified genomic DNA was amplified using primers that were specific for methylated (M) and unmethylated $(U)$ DNA. ${ }^{70}$ The sequences of the M-specific primers were $5^{\prime}$-GGGCGTTTTATTGGGCGTAT-3' $(-485$ to -466 from the ATG) and $5^{\prime}$-AAACCAACAATCAACGAAAC- $3^{\prime}$ ( -291 to -309 from the ATG). The sequences of the U-specific primers were $5^{\prime}$-GGGTGTTTTATTGGGTGTAT- $3^{\prime}$ and $5^{\prime}$-AAAC CAACAATCAACAAAAC- $3^{\prime}$. For sequencing analysis, bisulfite-modified genomic DNA was amplified using primers $5^{\prime}$ - TTATTATTAGTATTTAGTTAAGTTT- $3^{\prime}$ and $5^{\prime}$-CCTAAATACCAAAAAACCTAC- $3^{\prime}$, designed to amplify nucleotides -639 to -140 from the ATG of the WIF1 promoter region as previously described. ${ }^{71}$ Following PCR, the products were run in $1 \%$ agarose, then cut, blunted by standard protocol and cloned into pJET 1.2 vector. Five colonies were randomly chosen, colony PCR was carried out and sequenced.

Loss of heterozygosity. $\mathrm{LOH}$ analysis was performed as we described previously. ${ }^{18}$ In brief, PCR was performed in $10 \mu$ reaction volumes containing $17 \mathrm{ng}$ of template DNA, $0.2 \mu \mathrm{M}$ of $\mathrm{M} 13$ tailed primers (Research Genetics, Huntsville, AL, USA), $0.05 \mu \mathrm{M}$ of IR40-labeled M13 primer (Li-Cor, Lincoln, NE, USA), $200 \mu \mathrm{M}$ of each nucleotide, $10 \mathrm{mM}$ Tris $\mathrm{HCl}(\mathrm{pH} 8.3), 1.5 \mathrm{mM} \mathrm{MgCl}_{2}$ and 0.4 units of Taq DNA polymerase. Amplified fragments were detected using $6 \%$ polyacrylamide gels electrophoresed on automated Li-Cor model 4000 DNA sequencers. Gel images were collected using BASE IMAGIR version 2.0 software and the allelic scorings were done independently by three investigators. Allelic loss was confirmed by a second PCR and by running a second electrophoresis.

WIF1 construct. WIF1 was amplified from testis CDNA with the primers 5'-GAGATCTCTCGAGAGGAGGTCCTGAGCAGCATG-3' and 5'-TACCGCGGCC GCTAATGGTGATGGTGATGGTGCCAGATGTAATTGGATTCAGGTG-3', cloned in pGEM-T-EASY vector and sequenced. The pGEM-T WIF1 insert was then digested with $\mathrm{Xhol}$ and Notl, cloned into $\mathrm{pCl}$ blast $\mathrm{XhOl}$ and Notl sites. Insertion sites were confirmed by sequencing.

Cell lines. The cell lines used in this study were established from primary benign (PAs (PA37 and PA116)) and malignant (CaExPA79) salivary gland tumors, are immortalized and have been extensively characterized. ${ }^{26,72}$ Cell line identity was verified by DNA genotyping by short tandem repeat profiling (Genetic Resources Core Facility at Johns Hopkins University, Baltimore, MD, USA).

Treatment with DAC. Salivary gland tumor cell lines were treated with the demethylating agent DAC $(50 \mu \mathrm{M})$ for 4 days. Total RNA and genomic DNA were 
isolated and subjected to real-time reverse transcription-PCR (RT-PCR) and MSP respectively.

Real-time RT-PCR analysis. Total RNA was isolated from cells using TRIzol reagent (Invitrogen, CA, USA) and subjected to RT with Superscript II RNase $\mathrm{H}$-reverse transcriptase and random hexanucleotide primers (Invitrogen). The CDNA was subsequently used for real-time RT-PCR by SYBR chemistry (SYBR Green I; Molecular Probes, Eugene, OR, USA) using gene-specific primers (Supplementary Table 1) and Jumpstart Taq DNA polymerase (Sigma-Aldrich). The crossing threshold value determined by real-time RT-PCR was noted for the transcripts and normalized with $\beta$-actin or U6 pri-miRNA. The changes in mRNA were expressed as fold change relative to control with \pm S.D. value.

Transfection and proliferation assay. Exponentially growing salivary gland tumor cells were plated onto 96-well plates at the density of $1 \times 10^{4}$ cells/ well and transfected with either $\mathrm{pCl}$ blast (empty vector) or $\mathrm{pCl}$ blast-WIF1 using LipoD293 transfection reagent as per manufacturer's instruction (SignaGen Laboratories, ljamsville, MD, USA). The transfection efficiency is $\sim 55 \%$ for all cell lines used in this study. Cell proliferation was assessed at different time intervals (24, 48 and $72 h)$ by hexosaminidase assay. ${ }^{73}$ The relative cell growth (proliferation) was determined by normalizing the cells with the respective control (i.e., vector) as we described previously. ${ }^{21}$

ELISA. The concentration of WIF1 in the conditioned media was measured at 2, 5 and 14 days of WIF1 post transfection using the solid-phase sandwich ELISA kit (Aviscera Bioscience, Santa Clara, CA; sensitivity, $10 \mathrm{pg} / \mathrm{ml}$; intra and inter-assay CV, $4-8 \%$ and $8-12 \%$, respectively), according to the manufacturer's instruction.

Cell cycle analysis. PA116 and CaExPA79 $\left(3 \times 10^{5}\right.$ cells/well) were plated onto six-well plates and transfected with either empty vector or $\mathrm{pCl}$ blast-WIF1 for $48 \mathrm{~h}$ using LipoD293, and cell cycle analysis was performed as we described previously. ${ }^{21}$ In brief, the floating and attached cells were collected and centrifuged at 1000 r.p.m. for $5 \mathrm{~min}$. The supernatant was discarded, and the cells were washed and suspended in PBS. Single-cell suspension was fixed in ice-cold $70 \%$ ethanol for $2 \mathrm{~h}$ at $4{ }^{\circ} \mathrm{C}$. The cells were centrifuged to remove the ethanol and washed with PBS. The fixed cells were then incubated with $1 \mathrm{mg} / \mathrm{ml}$ propidium iodide (Sigma-Aldrich), 0.1\% Triton X-100 (Sigma-Aldrich) and $2 \mu \mathrm{g}$ DNase-free RNase (Sigma-Aldrich) in PBS for $30 \mathrm{~min}$ at room temperature in dark. Flow cytometry was done with a FACSCalibur analyzer (Becton Dickinson, Mountain View, CA, USA), capturing 50000 events for each sample. Results were analyzed with ModFit LT software (Verity Software House, Topsham, ME, USA).

Luciferase reporter gene assay. PA116 and CaExPA79 cells $\left(3 \times 10^{5}\right.$ cells/well) were plated onto six-well plates and transfected with either empty vector or $\mathrm{pCl}$ blast-WIF1 using LipoD293 for $24 \mathrm{~h}$ along with a plasmid containing firefly luciferase gene with a complementary miR-200c binding site in the $3^{\prime}$ UTR (miR-200c-Luc reporter vector) and plasmid pRL-TK that encodes Renilla luciferase to control for transfection efficiency. Luciferase activity was determined with dual-luciferase reporter assay system (Promega, Madison, WI, USA) as we described. $^{74}$

Senescence $\boldsymbol{\beta}$-galactosidase staining. PA116 and CaExPA79 cells $\left(3 \times 10^{5}\right.$ cells/well) were plated onto six-well plates and transfected with either empty vector or $\mathrm{pCl}$ blast-WIF1 using LipoD293 for $48 \mathrm{~h}$. The senescence assay was performed using senescence $\beta$-galactosidase staining kit (Cell Signaling Technology, Beverly, MA, USA) as per manufacturer's instruction.

Western blot analysis. Protein expression was studied by western blot analysis as we described previously. ${ }^{21}$ Cells were lysed in cell lysis buffer (Cell Signaling Technology) and further sonicated and centrifuged at 12000 r.p.m. for 10 min at $4{ }^{\circ} \mathrm{C}$. Fifty microgram proteins per lane were separated on $10 \%$ sodium dodecyl sulfate-polyacrylamide gel electrophoresis and electrotransferred to Immobilon-P membranes (Millipore, Bedford, MA, USA). The membranes were blocked for $1 \mathrm{~h}$ with $5 \%$ non-fat milk and incubated overnight with p53, p21 and Actin (Santa Cruz Biotechnology). This was followed by incubation with secondary antibodies coupled with HRP (Santa Cruz Biotechnology) for $1 \mathrm{~h}$ at room temperature. The membrane was then washed thrice in TBS-T. Immunoreactive antibody-antigen complexes were visualized with the enhanced chemiluminescence reagents (Thermo Scientific, Rockford, IL, USA).
ALDEFLUOR assay. PA116 and CaExPA79 cells were grown to $90 \%$ confluency in $100 \mathrm{~mm}$ petriplate and transfected with either empty vector or $\mathrm{pCl}$ blast-WIF1 using LipoD293 for $48 \mathrm{~h}$. Stem cells were sorted with Influx-V cell sorter (Cytopeia/BD, Franklin Lakes, NJ, USA) using ALDEFLUOR kit as per manufacturer's instruction (STEMCELL Technologies Inc., Vancouver, BC, Canada).

Spheroid assay. The anchorage-independent growth was determined by clonogenic assay as we previously described. ${ }^{72}$ The $1 \%$ agar was added without any enrichment onto 24-well plate in culture medium. Then the empty vector or $\mathrm{pCl}$ blast-WIF1-transfected cells were trypsinized and counted. The cell suspension $\left(1 \times 10^{4}\right.$ cells) were mixed with equal volume of growth medium containing agar $(0.6 \%)$ so that final concentration of agar becomes $0.3 \%$, which was overlaid onto the bottom layer. The cells were cultured for 2 weeks at $37^{\circ} \mathrm{C}$ in a $5 \% \mathrm{CO}_{2}$ incubator. Colonies consisting of $>10$ cells were counted on day 5 and 14.

Statistical analysis. Statistical analyses were performed using SAS STAT version 9.1 (SAS Institute Inc., Cary, NC, USA). Independent means were compared using unpaired Student's t-tests whose degrees of freedom were corrected, when appropriate, for inequality of variance.

\section{Conflict of Interest}

The authors declare no conflict of interest.

Acknowledgements. We sincerely thank Dr. Eric W Howard for kindly providing the $\mathrm{pCl}$ blast vector. We thank Dr. Thavathiru Elangovan, Mrs. Geraldine A Chissoe, Mrs. Susan Nagelhout (Cancer Registry Manager), Mr. Jeremy K Jinkins and Mr. Randal May (Advanced Immunohistochemistry \& Morphology Core, OUHSC) for their assistance, technical advice and graphical assistance. We very much appreciate the helpful discussions of Dr. Sivakumar Ramadoss (UCLA) and Dr. R lleng Kumaran (CSHL). This work was supported by the Oklahoma Center for the Advancement of Science \& Technology (to LQ; HR08-018). LQ holds a Presbyterian Health Foundation Endowed Chair in Otorhinolaryngology (EC221800) Position.

1. Speight PM, Barrett AW. Salivary gland tumours. Oral Dis 2002; 8: 229-240.

2. Olsen KD, Lewis JE. Carcinoma ex pleomorphic adenoma: A clinicopathologic review. Head Neck 2001; 23: 705-712.

3. Antony J, Gopalan V, Smith RA, Lam AK. Carcinoma ex pleomorphic adenoma: a comprehensive review of clinical, pathological and molecular data. Head Neck Pathol 2012; 6: 1-9.

4. Clevers H. Wnt/beta-catenin signaling in development and disease. Cell 2006; 127: 469-480.

5. Polakis P. The many ways of Wnt in cancer. Curr Opin Genet Dev 2007; 17: 45-51.

6. Logan CY, Nusse R. The Wnt signaling pathway in development and disease. Annu Rev Cell Dev Biol 2004; 20: 781-810.

7. Anastas JN, Moon RT. WNT signalling pathways as therapeutic targets in cancer. Nat Rev Cancer 2013; 13: 11-26.

8. Zhao C, Blum J, Chen A, Kwon HY, Jung SH, Cook JM et al. Loss of beta-catenin impairs the renewal of normal and CML stem cells in vivo. Cancer Cell 2007; 12: 528-541.

9. Wang Y, Krivtsov AV, Sinha AU, North TE, Goessling W, Feng Z et al. The Wnt/betacatenin pathway is required for the development of leukemia stem cells in AML. Science 2010; 327: 1650-1653.

10. Yeung J, Esposito MT, Gandillet A, Zeisig BB, Griessinger E, Bonnet D et al. beta-Catenin mediates the establishment and drug resistance of MLL leukemic stem cells. Cancer Cell 2010; 18: 606-618.

11. Verras M, Brown J, Li X, Nusse R, Sun Z. Wnt3a growth factor induces androgen receptormediated transcription and enhances cell growth in human prostate cancer cells. Cancer Res 2004; 64: 8860-8866.

12. Chien AJ, Moore EC, Lonsdorf AS, Kulikauskas RM, Rothberg BG, Berger AJ et al. Activated Wnt/beta-catenin signaling in melanoma is associated with decreased proliferation in patient tumors and a murine melanoma model. Proc Natl Acad Sci USA 2009; 106: 1193-1198.

13. Yoshioka S, King ML, Ran S, Okuda H, MacLean 2nd JA, McAsey ME et al. WNT7A regulates tumor growth and progression in ovarian cancer through the WNT/beta-catenin pathway. Mol Cancer Res 2012; 10: 469-482.

14. Ochoa-Hernandez AB, Ramos-Solano M, Meza-Canales ID, Garcia-Castro B Rosales-Reynoso MA, Rosales-Avina JA et al. Peripheral T-lymphocytes express WNT7A 
and its restoration in leukemia-derived lymphoblasts inhibits cell proliferation. BMC Cancer 2012; 12: 60

15. Oishi N, Wang XW. Novel therapeutic strategies for targeting liver cancer stem cells. Int J Biol Sci 2011; 7: 517-535.

16. Fonseca I, Fonseca R, Martins C, Soares J. Alteration of beta-catenin localization in salivary pleomorphic adenomas is not related to $t(3 ; 8)(p 21 ; q 12)$ and is mainly present in non-epithelial cell types. Histopathology 2008; 52: 244-247.

17. do Prado RF, Consolaro A, Taveira LA. Expression of betacatenin in carcinoma in pleomorphic adenoma, pleomorphic adenoma and normal salivary gland: an immunohistochemical study. Med Oral Patol Oral Cir Bucal 2006; 11: E247-E251.

18. Queimado L, Lopes CS, Reis AM. WIF1, an inhibitor of the Wnt pathway, is rearranged in salivary gland tumors. Genes Chromosomes Cancer 2007; 46: 215-225.

19. Hsieh JC, Kodjabachian L, Rebbert ML, Rattner A, Smallwood PM, Samos CH et al. A new secreted protein that binds to Wnt proteins and inhibits their activities. Nature 1999; 398: 431-436.

20. Wissmann C, Wild P, Kaiser S, Roepcke S, Stoehr R, Woenckhaus M et al. WIF1, a component of the Wnt pathway, is down-regulated in prostate, breast, lung, and bladder cancer. J Pathol 2003; 201: 204-212.

21. Ramachandran I, Thavathiru E, Ramalingam S, Natarajan G, Mills WK, Benbrook DM et al. Wnt inhibitory factor 1 induces apoptosis and inhibits cervical cancer growth, invasion and angiogenesis in vivo. Oncogene 2012; 31: 2725-2737.

22. Kawakami K, Hirata H, Yamamura S, Kikuno N, Saini S, Maijd S et al. Functiona significance of Wnt inhibitory factor-1 gene in kidney cancer. Cancer Res 2009; 69: 8603-8610.

23. Kansara M, Tsang M, Kodjabachian L, Sims NA, Trivett MK, Ehrich M et al. Wnt inhibitory factor 1 is epigenetically silenced in human osteosarcoma, and targeted disruption accelerates osteosarcomagenesis in mice. J Clin Invest 2009; 119: 837-851.

24. Ai L, Tao Q, Zhong S, Fields CR, Kim W-J, Lee MW et al. Inactivation of Wnt inhibitory factor-1 (WIF1) expression by epigenetic silencing is a common event in breast cancer Carcinogenesis 2006; 27: 1341-1348.

25. El-Naggar AK, Callender D, Coombes MM, Hurr K, Luna MA, Batsakis JG. Molecular genetic alterations in carcinoma ex-pleomorphic adenoma: a putative progression model? Genes Chromosomes Cancer 2000; 27: 162-168.

26. Queimado L, Obeso D, Hatfield MD, Yang Y, Thompson DM, Reis AMC. Dysregulation of Wnt pathway components in human salivary gland tumors. Arch Otolaryngol Head Neck Surg 2008; 134: 94-101

27. Kuilman T, Michaloglou C, Mooi WJ, Peeper DS. The essence of senescence. Genes Dev 2010; 24: 2463-2479.

28. Zeng YA, Nusse R. Wnt proteins are self-renewal factors for mammary stem cells and promote their long-term expansion in culture. Cell Stem Cell 2010; 6: 568-577.

29. Marcato P, Dean CA, Giacomantonio CA, Lee PW. Aldehyde dehydrogenase: its role as a cancer stem cell marker comes down to the specific isoform. Cell Cycle 2011; 10: 1378-1384.

30. Sun S, Wang Z. ALDH high adenoid cystic carcinoma cells display cancer stem cell properties and are responsible for mediating metastasis. Biochem Biophys Res Commun 2010; 396: 843-848.

31. Zhou JH, Hanna EY, Roberts D, Weber RS, Bell D. ALDH1 immunohistochemical expression and its significance in salivary adenoid cystic carcinoma. Head Neck 2013; 35 575-578.

32. Adams A, Warner K, Nor JE. Salivary gland cancer stem cells. Oral Oncol 2013; 49 845-853.

33. Kashyap V, Rezende NC, Scotland KB, Shaffer SM, Persson JL, Gudas LJ et al. Regulation of stem cell pluripotency and differentiation involves a mutual regulatory circuit of the NANOG, OCT4, and SOX2 pluripotency transcription factors with polycomb repressive complexes and stem cell microRNAs. Stem Cells Dev 2009; 18 1093-1108.

34. Li Y, Zhang Q, Yin X, Yang W, Du Y, Hou $P$ et al. Generation of iPSCs from mouse fibroblasts with a single gene, Oct4, and small molecules. Cell Res 2011; 21 196-204.

35. Luis TC, Weerkamp F, Naber BAE, Baert MRM, de Haas EFE, Nikolic T et al. Wnt3a deficiency irreversibly impairs hematopoietic stem cell self-renewal and leads to defects in progenitor cell differentiation. Blood 2009; 113: 546-554.

36. Lu R, Qu Y, Ge J, Zhang L, Su Z, Pflugfelder SC et al. Transcription factor TCF4 maintains the properties of human corneal epithelial stem cells. Stem Cells 2012; 30: 753-761.

37. Mitani Y, Li J, Rao PH, Zhao YJ, Bell D, Lippman SM et al. Comprehensive analysis of the MYB-NFIB gene fusion in salivary adenoid cystic carcinoma: Incidence, variability, and clinicopathologic significance. Clin Cancer Res 2010; 16: 4722-4731.

38. Stenman $G$, Andersson MK, Andren $Y$. New tricks from an old oncogene: gene fusion and copy number alterations of MYB in human cancer. Cell Cycle 2010; 9: 2986-2995.

39. Cros J, Sbidian E, Hans S, Roussel H, Scotte F, Tartour E et al. Expression and mutational status of treatment-relevant targets and key oncogenes in 123 malignant salivary gland tumours. Ann Oncol 2013; 24: 2624-2629.

40. Lieu YK, Reddy EP. Conditional c-myb knockout in adult hematopoietic stem cells leads to loss of self-renewal due to impaired proliferation and accelerated differentiation. Proc Nat Acad Sci USA 2009; 106: 21689-21694.

41. Cheasley D, Pereira L, Lightowler S, Vincan E, Malaterre J, Ramsay RG. Myb controls intestinal stem cell genes and self-renewal. Stem Cells 2011; 29: 2042-2050.
42. Kimura Y, Ding B, Imai N, Nolan DJ, Butler JM, Rafii S. c-Kit-mediated functional positioning of stem cells to their niches is essential for maintenance and regeneration of adult hematopoiesis. PLoS One 2011; 6: e26918.

43. Lombaert IM, Brunsting JF, Wierenga PK, Faber H, Stokman MA, Kok T et al. Rescue of salivary gland function after stem cell transplantation in irradiated glands. PLoS One 2008; 3: e2063.

44. Gangaraju VK, Lin H. MicroRNAs: key regulators of stem cells. Nat Rev Mol Cell Biol 2009; 10: $116-125$.

45. Zhang X, Cairns M, Rose B, O'Brien C, Shannon K, Clark J et al. Alterations in miRNA processing and expression in pleomorphic adenomas of the salivary gland. Int $\mathrm{J}$ Cancer 2009; 124: 2855-2863.

46. Hayashi T, Koyama N, Mizukoshi K, Kashimata M. MicroRNA profiling methods applied to recent studies of fetal mouse submandibular gland development. J Oral Biosci 2012; 54: 169-172.

47. Yu F, Yao H, Zhu $P$, Zhang $X$, Pan $Q$, Gong $C$ et al. let-7 regulates self renewal and tumorigenicity of breast cancer cells. Cell 2007; 131: 1109-1123.

48. Iwaya T, Yokobori T, Nishida N, Kogo R, Sudo T, Tanaka F et al. Downregulation of miR-144 is associated with colorectal cancer progression via activation of mTOR signaling pathway. Carcinogenesis 2012; 33: 2391-2397.

49. Park IK, Morrison SJ, Clarke MF. Bmi1, stem cells, and senescence regulation. $J$ Clin Invest 2004; 113: 175-179.

50. Shimono Y, Zabala M, Cho RW, Lobo N, Dalerba P, Qian D et al. Downregulation of miRNA-200c links breast cancer stem cells with normal stem cells. Cell 2009; 138: 592-603.

51. Magenta A, Cencioni C, Fasanaro P, Zaccagnini G, Greco S, Sarra-Ferraris G et al. $\mathrm{miR}-200 \mathrm{C}$ is upregulated by oxidative stress and induces endothelial cell apoptosis and senescence via ZEB1 inhibition. Cell Death Differ 2011; 18: 1628-1639.

52. Lo WL, Yu CC, Chiou GY, Chen YW, Huang PI, Chien CS et al. MicroRNA-200c attenuates tumour growth and metastasis of presumptive head and neck squamous cell carcinoma stem cells. J Pathol 2011; 223: 482-495.

53. Sanchez-Tillo E, Fanlo L, Siles L, Montes-Moreno S, Moros A, Chiva-Blanch G et al. The EMT activator ZEB1 promotes tumor growth and determines differential response to chemotherapy in mantle cell lymphoma. Cell Death Differ 2014; 21: 247-257.

54. Kim J, You L, Xu Z, Kuchenbecker K, Raz D, He B et al. Wnt inhibitory factor inhibits lung cancer cell growth. J Thorac Cardiovasc Surg 2007; 133: 733-737.

55. Tang Y, Simoneau AR, Liao WX, Yi G, Hope C, Liu F et al. WIF1, a Wnt pathway inhibitor, regulates SKP2 and c-myc expression leading to $\mathrm{G} 1$ arrest and growth inhibition of human invasive urinary bladder cancer cells. Mol Cancer Ther 2009; 8: 458-468.

56. Hanahan D, Weinberg RA. Hallmarks of cancer: the next generation. Cell 2011; 144: 646-674.

57. Lambiv WL, Vassallo I, Delorenzi M, Shay T, Diserens AC, Misra A et al. The Wnt inhibitory factor 1 (WIF1) is targeted in glioblastoma and has a tumor suppressing function potentially by induction of senescence. Neuro Oncol 2011; 13: 736-747.

58. Zhang DY, Pan Y, Zhang C, Yan BX, Yu SS, Wu DL et al. Wnt/beta-catenin signaling induces the aging of mesenchymal stem cells through promoting the ROS production. Mol Cell Biochem 2013; 374: 13-20.

59. Agarwal ML, Agarwal A, Taylor WR, Stark GR. p53 controls both the $G_{2} / M$ and the $G_{1}$ cell cycle checkpoints and mediates reversible growth arrest in human fibroblasts. Proc Nat Acad Sci USA 1995; 92: 8493-8497.

60. Trifa F, Karray-Chouayekh S, Jmal E, Jmaa ZB, Khabir A, Sellami-Boudawara T et al. Loss of WIF-1 and Wnt5a expression is related to aggressiveness of sporadic breast cancer in Tunisian patients. Tumour Biol 2013; 34: 1625-1633.

61. Kim NH, Kim HS, Kim NG, Lee I, Choi HS, Li XY et al. p53 and microRNA-34 are suppressors of canonical Wnt signaling. Sci Signal 2011; 4: ra71.

62. Sadot E, Geiger B, Oren M, Ben-Ze'ev A. Down-regulation of beta-catenin by activated p53. Mol Cell Biol 2001; 21: 6768-6781.

63. Baker EK, Purton LE. A stressed niche not Wnted. Blood 2011; 118: 2377-2378.

64. Surmann-Schmitt C, Widmann N, Dietz U, Saeger B, Eitzinger N, Nakamura Y et al. Wif-1 is expressed at cartilage-mesenchyme interfaces and impedes Wnt3a-mediated inhibition of chondrogenesis. J Cell Sci 2009; 122: 3627-3637.

65. Takahashi K, Tanabe K, Ohnuki M, Narita M, Ichisaka T, Tomoda K et al. Induction of pluripotent stem cells from adult human fibroblasts by defined factors. Cell 2007; 131: 861-872.

66. Hai B, Yang Z, Millar SE, Choi YS, Taketo MM, Nagy A et al. Wnt/beta-catenin signaling regulates postnatal development and regeneration of the salivary gland. Stem Cells Dev 2010; 19: 1793-1801.

67. Rebustini IT, Hayashi T, Reynolds AD, Dillard ML, Carpenter EM, Hoffman MP. miR-200c regulates FGFR-dependent epithelial proliferation via VIdlr during submandibular gland branching morphogenesis. Development 2012; 139: 191-202.

68. Barnes L, Eveson J, Reichart P, Sidransky D. Pathology and Genetics of Head and Neck Tumours. IARC Press: Lyon, France, 2005.

69. Queimado L, Reis A, Fonseca I, Martins C, Lovett M, Soares J et al. A refined localization of two deleted regions in chromosome $6 \mathrm{q}$ associated with salivary gland carcinomas. Oncogene 1998; 16: 83-88.

70. Herman JG, Graff JR, Myohanen S, Nelkin BD, Baylin SB. Methylation-specific PCR: a novel PCR assay for methylation status of CpG islands. Proc Natl Acad Sci USA 1996; 93: $9821-9826$. 
71. Mazieres J, He B, You L, Xu Z, Lee AY, Mikami I et al. Wnt inhibitory factor-1 is silenced by promoter hypermethylation in human lung cancer. Cancer Res 2004; 64: 4717-4720.

72. Queimado L, Lopes C, Du F, Martins C, Fonseca I, Bowcock AM et al. In vitro transformation of cell lines from human salivary gland tumors. Int $\mathrm{J}$ Cancer 1999; 81: 793-798.

73. Landegren U. Measurement of cell numbers by means of the endogenous enzyme hexosaminidase. Applications to detection of lymphokines and cell surface antigens. J Immunol Methods 1984; 67: 379-388.

74. Ramalingam S, Natarajan G, Schafer C, Subramaniam D, May R, Ramachandran I et al. Novel intestinal splice variants of RNA-binding protein CUGBP2: isoform-specific effects on mitotic catastrophe. Am J Physiol Gastrointest Liver Physiol 2008; 294: G971-G981.
Cell Death and Disease is an open-access journal published by Nature Publishing Group. This work is licensed under a Creative Commons Attribution-NonCommercialNoDerivs 3.0 Unported License. The images or other third party material in this article are included in the article's Creative Commons license, unless indicated otherwise in the credit line; if the material is not included under the Creative Commons license, users will need to obtain permission from the license holder to reproduce the material. To view a copy of this license, visit http://creativecommons.org/ licenses/by-nc-nd/3.0/

Supplementary Information accompanies this paper on Cell Death and Disease website (http://www.nature.com/cddis) 